\title{
Integration of exotic seeds into an Azorean seed dispersal network
}

\author{
Ruben H. Heleno • Jaime A. Ramos • \\ Jane Memmott
}

Received: 2 March 2012/ Accepted: 19 November 2012

(C) Springer Science+Business Media Dordrecht 2012

\begin{abstract}
Seed dispersal plays a central role in plant ecology. Among animals, birds are particularly important seed dispersers, often incorporating exotic plants into their diets and facilitating their integration in the communities. Network theory offers a highly informative framework to study the structural and functional attributes of complex interactions networks. We used information from bird fecal samples to build a quantitative seed dispersal network for the last fragment of native laurel forest in the island of São Miguel-Azores with three specific objectives: (1) to assess the integration of exotic seeds into seed dispersal; (2) to evaluate the impact of exotic plants in network structure; (3) to test the potential of an exotic species to reduce the seed dispersal of a co-occurring native, via competition for seed dispersers. The seed dispersal network was based on the analysis of 1,121 droppings and described 74 unique interactions between 41 plant species and 7 bird
\end{abstract}

R. H. Heleno $(\bowtie)$

Centre for Functional Ecology, Department of Life Sciences, University of Coimbra, P.O. Box 3046, 3001-401 Coimbra, Portugal

e-mail: rheleno@uc.pt

J. A. Ramos

Institute of Marine Research (IMAR/CMA),

Department of Life Sciences, University of Coimbra,

Coimbra, Portugal

J. Memmott

School of Biological Sciences, University of Bristol,

Bristol, UK species. Exotic seeds deeply infiltrated into the seed dispersal network forming the majority (59\%) of seeds in the droppings and including those of three globally invasive plants. Overall, birds depended equally on native and exotic fruits despite the lower abundance of the latter in the study area. In an experiment, birds did not show a preference for fruits of the exotic Leycesteria formosa over the native Vaccinium cylindraceum consuming them equally. However, the presence of the exotic plant negatively affected the number of native seeds dispersed, by diverting some of the consumers of the native fruits. Taken altogether the results reveal an alarming invasion level of seed dispersal systems in one of the last remnant native forests of the Azores.

Keywords Azores - Ecosystem services · Exotic plants · Laurel forest · Plant invasions . Seed rain

\section{Introduction}

Seed dispersal is a key process that, to a great extent, determines plant spatial structure, population dynamics and long-term species persistence (Nathan and Muller-Landau 2000). However, seed dispersal is not only important for the regeneration of natural vegetation but it can also facilitate the spread of exotic plant species (Traveset and Richardson 2011). Indeed, it is frequently documented that the incorporation of exotic plant seeds into the diet of frugivores can be an 
important step in that species becoming invasive (e.g. Bartuszevige and Gorchov 2006; Buckley et al. 2006; Williams 2006). Given the impact of plant invasions throughout the world (e.g. Vitousek et al. 1996), understanding seed dispersal can give an important contribution for planning effective wildlife conservation strategies, particularly those involving the conservation of rare plants and the control or eradication of fleshy-fruited weeds (Gosper et al. 2005; Buckley et al. 2006). The growing recognition that speciesinteractions patterns, and not only species-lists, are particularly important for the understanding of many ecosystem functions (MEA 2005; Duffy et al. 2007; Memmott et al. 2007), has lead ecologists to invest a considerable amount of effort in documenting the interactions between plants and their animal dispersers. However, these efforts focus mainly on the identification of the plants dispersed by specific introduced animals (e.g. Williams 2006; Milton et al. 2007; Kawakami et al. 2009; Linnebjerg et al. 2010), or on the identification of the dispersers of focal invasive plants (e.g. Stansbury 2001; Cordeiro et al. 2004; Bartuszevige and Gorchov 2006). The quantification of the whole seed dispersal processes in naturally occurring communities native and exotic plants being simultaneously dispersed by a complex assemblage of frugivores has been rarely attempted (Buckley et al. 2006), despite some notable efforts (e.g. Aslan and Rejmánek 2010; Heleno et al. 2012b). This lack of knowledge contrasts with the much better understanding of the disruptive effect of exotic plants on pollination networks, the other important reproductive mutualism for flowering plants (e.g. Memmott and Waser 2002; Olesen et al. 2002; Carvalheiro et al. 2008; Traveset and Richardson 2011).

It is now widely recognized that the disruption of these species-interaction networks can have a profound impact on the communities' response to environmental disturbance and ecological restoration (Dunne et al. 2002; Estrada 2007; Heleno et al. 2010). Knowledge on the structure and function of such mutualisms is particularly urgent on oceanic islands where recently introduced species are rapidly eroding communities which typically evolved under relaxed competitive pressure (MacArthur and Wilson 1967; Whittaker and Fernández-Palacios 2007). In this study we use seed dispersal networks to evaluate the dispersal of exotic seeds in one of the last fragments of native forest in the archipelago of the Azores.
This study has three specific objectives: (1) To evaluate the extent to which exotic plants infiltrate the seed dispersal network, and the importance of native and exotic fruits and seeds as resources for birds. We predict that in this remnant native forest frugivorous birds will depend mostly on native fruits, however given the generalized nature of most plant-frugivores interactions (Jordano 1987; Berlow 1999), we expect that exotic fruits will be easily integrated by foraging birds which will disperse their seeds (2) To determine how exotic plants change the structure of a seed dispersal network. Many exotic species are particularly attractive to many frugivores (Renne et al. 2002), thus the consumption of their fruits is likely to increase network-level parameters which are directly related to the number of interactions established by species within a community, such as linkage density, connectance and robustness. (3) To use a field experiment to test whether an exotic plant species can reduce the seed dispersal of a co-occurring native plant. If the integration of exotic fruits into seed dispersal networks occurs by diverting some of the services previously allocated to disperse native seeds, we expect that the number of native fruits dispersed is reduced when native and exotic plants with similar fruit traits and phenology are in direct competition for dispersers.

\section{Methods}

Study site

The study was conducted in Serra da Tronqueira, a mountainous district in the East of the Island of São Miguel, Azores, Portugal which holds the last fragment (c. 815 ha; SPEA 2005) of native forests in the archipelago - the Laurel forest (Fig. 1). The laurel forests of the Atlantic islands are considered relicts of the Palaeotropical vegetation composed by broadleaved, evergreen trees and shrubs with a relatively low canopy and dense understory of shrubs and ferns (Schaeffer 2002; Dias et al. 2007; Fernandez-Palacios et al. 2011). In the Azores the most representative species are endemic to the archipelago: Laurus azorica, Juniperus brevifolia, Ilex perado spp. azorica, Erica azorica and Vaccinium cylindraceum (Schaeffer 2002; Dias et al. 2007). The Azores have a temperate oceanic climate, with high relative humidity 
Fig. 1 Location of field sites. Open circles indicate field sites where bird fecal samples were collected. Closed circles indicate field sites where fecal samples were collected and plant abundance and bird density was estimated

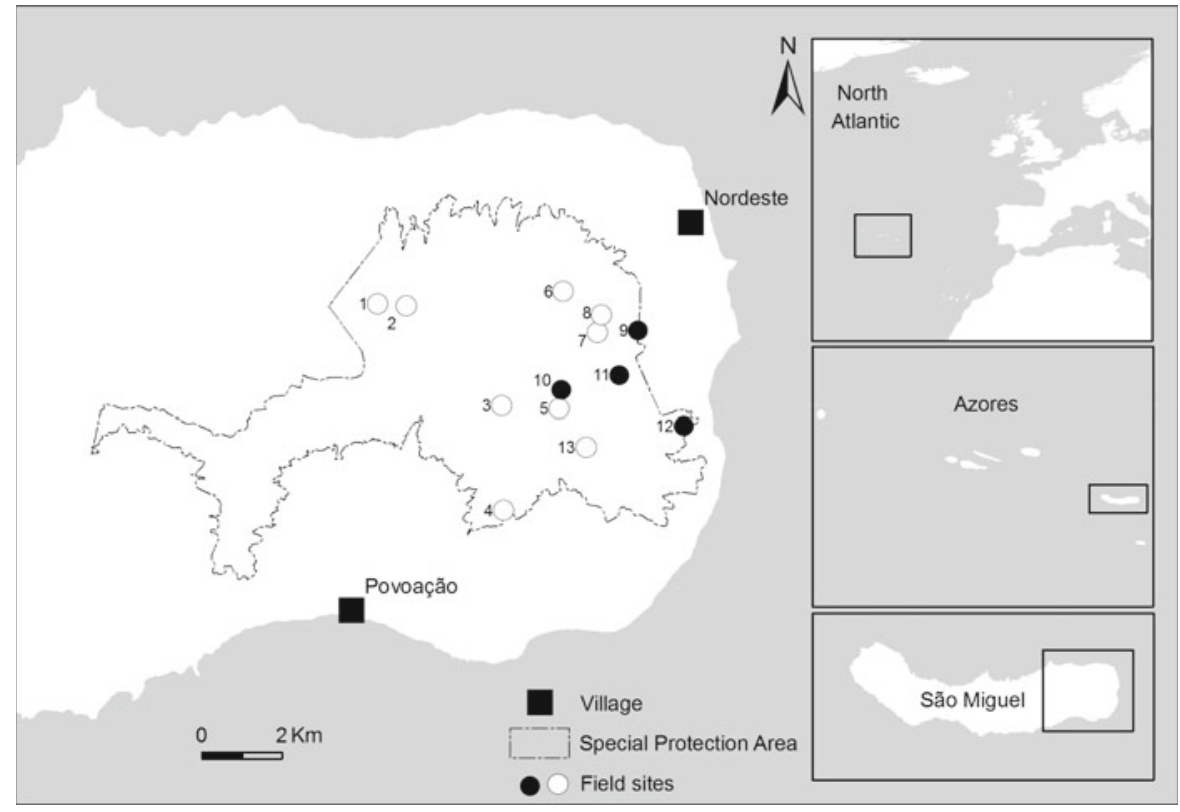

\begin{tabular}{lll}
\hline Map code & Name & Geographic coordinates \\
\hline 1 & Bardinho & $37^{\circ} 48^{\prime} 54,428^{\prime \prime} \mathrm{N} ; 25^{\circ} 14^{\prime} 13,126^{\prime \prime} \mathrm{W}$ \\
2 & Algarvia & $37^{\circ} 48^{\prime} 52,314^{\prime \prime} \mathrm{N} ; 25^{\circ} 13^{\prime} 43,834^{\prime \prime} \mathrm{W}$ \\
3 & Trilhos Novos & $37^{\circ} 47^{\prime} 30,230^{\prime \prime} \mathrm{N} ; 25^{\circ} 12^{\prime} 08,870^{\prime \prime} \mathrm{W}$ \\
4 & Pico da Feteira & $37^{\circ} 46^{\prime} 05,587^{\prime \prime} \mathrm{N} ; 25^{\circ} 12^{\prime} 08,843^{\prime \prime} \mathrm{W}$ \\
5 & Estrada da Tronqueira & $37^{\circ} 47^{\prime} 26,891^{\prime \prime} \mathrm{N} ; 25^{\circ} 11^{\prime} 10,470^{\prime \prime} \mathrm{W}$ \\
6 & Malhada & $37^{\circ} 49^{\prime} 01,658^{\prime \prime} \mathrm{N} ; 25^{\circ} 11^{\prime} 03,751^{\prime \prime} \mathrm{W}$ \\
7 & Grotas Fundas & $37^{\circ} 48^{\prime} 27,797^{\prime \prime} \mathrm{N} ; 25^{\circ} 10^{\prime} 29,913^{\prime \prime} \mathrm{W}$ \\
8 & Fajã do Rodrigo & $37^{\circ} 48^{\prime} 41,913^{\prime \prime} \mathrm{N} ; 25^{\circ} 10^{\prime} 25,218^{\prime \prime} \mathrm{W}$ \\
9 & Outeiro Alto & $37^{\circ} 48^{\prime} 28,981^{\prime \prime} \mathrm{N} ; 25^{\circ} 09^{\prime} 48,398^{\prime \prime} \mathrm{W}$ \\
10 & Miradouro da Tronqueira & $37^{\circ} 47^{\prime} 42,060^{\prime \prime} \mathrm{N} ; 25^{\circ} 11^{\prime} 07,350^{\prime \prime} \mathrm{W}$ \\
11 & Cancela do Cinzeiro & $37^{\circ} 47^{\prime} 53,178^{\prime \prime} \mathrm{N} ; 25^{\circ} 10^{\prime} 07,8466^{\prime \prime} \mathrm{W}$ \\
12 & Lombo Gordo & $37^{\circ} 47^{\prime} 11,134^{\prime \prime} \mathrm{N} ; 25^{\circ} 09^{\prime} 03,4966^{\prime \prime} \mathrm{W}$ \\
13 & Pico Bartolomeu & $37^{\circ} 46^{\prime} 55,387^{\prime \prime} \mathrm{N} ; 25^{\circ} 10^{\prime} 43,313^{\prime \prime} \mathrm{W}$ \\
\hline
\end{tabular}

and small temperature range (Tutin 1953). Native vegetation in São Miguel has been largely converted to pastures and replaced by plantations of Cryptomeria japonica, the remaining forest has been greatly invaded by aggressive weeds such as Pittosporum undulatum (Australian cheesewood), Hedychium gardnerianum (Kahili ginger), and Clethra arborea (Lilly-of-the-valley-tree) (Silva 2001).

Building the quantitative seed dispersal networks and estimating fruit abundance

A seed dispersal network was built for the Serra da Tronqueira, quantifying each seed-bird interaction (dispersal event) by analyzing bird fecal samples collected over 3 years. Due to their high mobility and frugivorous habits, birds are in many ecosystems, the most important seed dispersers (Herrera 1995) and they are likely the only relevant seed-dispersers in the Azorean native forests, due to the absence of reptiles and native mammals. Fecal samples were collected over the course of 3 years: April 2005 to November 2007 in 13 sites across the Special Protected Area of Serra da Tronqueira and Ribeira do Guilherme (Fig. 1). These sites were representative of the actual gradient of plant invasion of the native laurel forest in the study area. The decision of building a single network for the whole forest was based primarily in the objective of having a detailed and realistic characterization of the seed dispersal system at the landscape-unit that is managed by practitioners. All sites are imbedded in the same forest patch and are thus not fully independent as most bird species in the area are present throughout the study area and move 
frequently between sites (R. Heleno, unpublished data). Furthermore, the sampling effort allocated to each site was not uniform but proportional to the relative importance of each habitat class in the whole mountain range, with some sites receiving little effort, which would hinder any direct comparison of sitespecific networks. Given that this area contains the last remaining patch of native habitat on the island, using multiple forest patches was not an option.

The collection of fecal samples was conducted during ringing sessions with mist nets. In each session, mist nets were opened at sunrise and remained open for five consecutive hours. Mist nests (c. $60 \mathrm{~m}$ ) were erected approximately 6 times per month during the study period resulting in 193 ringing sessions (87, 45 and 61 in 2005, 2006 and 2007, respectively). Birds were kept inside ringing bags to defecate for a maximum of $30 \mathrm{~min}$ and droppings were stored in $70 \%$ ethanol for later analysis. All entire seeds in the droppings were identified under a dissecting microscope by comparison with a reference collection.

Dispersal effectiveness was visually incorporated into the networks by weighing the presence of intact seeds in bird droppings by the abundance of the disperser. This was calculated by multiplying the frequency of occurrence of intact seed species in the fecal samples (an important component of the quality of seed dispersal), by independent estimates of bird abundance (a measure of the quantitative component of seed dispersal) (Schupp et al. 2010). Because there are other factors affecting the quality of seed dispersal, such as the quality of the deposition site, which we have not considered, the measure proposed here is best considered as a proxy of the real dispersal effectiveness of each disperser. Bird abundance was obtained by recording birds with 8 -min point-counts, at 3 weeks intervals in four sites representative of the main levels of plant invasion (Fig. 1), from 1 May to 26 November 2005. The description of these sites and methods for estimating bird abundance are described in Heleno et al. (2011). The seed dispersal network was visualized using software written in Mathemati$\mathrm{ca}^{\circledR}$ (Wolfram Research 1999). In order to quantify fruit availability for dispersers, fruit production was estimated in the same four sites as bird abundance. Fruit production were sampled by counting all ripe standing fruits and seeds (hereafter collectively referred to as fruits) within a swathe of vegetation $1 \mathrm{~m}$ either side of $100 \mathrm{~m}$ linear transects. Fleshy fruits were individually counted while seeds from dryfruited families (e.g. Asteraceae, Cyperaceae) were quantified in terms of flower/seed-heads (e.g. Evans et al. 2011). When high fruit abundance made counting prohibitive, the number of fruits in smaller areas was assessed and extrapolated for the whole transect. Forest height did not pose a problem for fruit counts as most trees in the study sites were bellow $4 \mathrm{~m}$. Ten transects were run at each site at 3 weeks intervals from 1 May to 26 November 2005, this time interval incorporating the fruiting season of most plant species (Schaeffer 2002).

In order to evaluate the importance of native or exotic fruits for the bird community we evaluated plant species strength, i.e. the sum of each bird species relative dependencies on native or exotic plant species (Bascompte et al. 2006). The effect of plant abundance and origin on plant species strength (square root transformed) was evaluated with a General Linear Model. The frequency of occurrence of intact seeds on bird droppings was used as a proxy of bird dependency on each plant species.

\section{Evaluating network structure}

We tested the effect of the integration of exotic plants on five commonly used network descriptors which are likely to be influenced by species generalism. The following five descriptors were calculated for the whole seed dispersal network and for the alien and native sub-networks: (1) Connectance, i.e. the proportion of links that are realized among all possible links; (2) the mean number of dispersers per plant; (3) Linkage density, i.e. the mean number of interactions per species weighted by interaction frequency; (4) Interaction evenness, i.e. the Shannon's evenness of interaction frequencies (Bersier et al. 2002); and (5) Robustness, i.e. the effect of species loss on the network, measured in terms of linked extinctions (Dunne et al. 2002). All parameters were calculated using the R package Bipartite 1.16 (Dormann et al. 2008) and are described in Dormann et al. (2009); the first four descriptors are quantitative, i.e. incorporate a measure of interaction frequency, while robustness analysis is based on qualitative, i.e. presence only, data.

Because all of these indices are, to some extent, dependent on network size (Dormann et al. 2009), the direct comparison of parameter values is not fully informative. Thus, the results are also presented and 
discussed in terms of a "standardized" percentage of the observed value for each parameter relatively to the bench-mark value of the same parameter for randomly generated networks of the same size. Such randomly generated networks were created using the algorithms

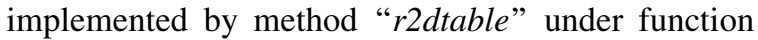
"nullmodel" in the package Bipartite (Dormann et al. 2008) for R (R Development Core Team 2010), and replicated 1,000 times. Observed values were considered to be significantly different from random if they were outside of the $95 \%$ confidence interval around the mean of each parameter (see Gibson et al. 2011; Montesinos-Navarro et al. 2012, and references therein).

Evaluating competition for seed dispersers

In order to evaluate if an exotic plant can appropriate the dispersers of native plants, thereby reducing the dispersal of native seeds, we compared the dispersal efficiency of the exotic Leycesteria formosa (Caprifoliaceae) and the native Vaccinium cylindraceum (Ericaceae). We focused on this particular pair of species because both are endozochorous producing berries with many small seeds, their fruits have similar size (6-9 mm), similar colour (dark purple when ripe) and similar caloric content (Mean $\pm \mathrm{SD}=4,468 \pm$ $51 \mathrm{cal} \mathrm{g}^{-1}$ and $4,737 \pm 403 \mathrm{cal} \mathrm{g}^{-1}$ for L. formosa and V. cylindraceum respectively; R. Ceia, unpublished data). Both species are abundant and ubiquitous in the study area (Fig. 2), their fruit display is very similar and they have overlapping fruiting phenologies, all suggesting that both species might directly compete for seed dispersers.

We quantified fruit removal from $V$. cylindraceum trees when isolated (i.e. pre-invasion) and when adjacent $(<2 \mathrm{~m})$ to $L$. formosa (i.e. post-invasion). The initial fruit load of each plant (both the native and the exotic) was reduced to 300 ripe fruits, and all flowers and flower buds were manually removed. Fallen fruits were collected with a net circling each plant, which was inspected every other day for 3 weeks, at which time the number of fruits remaining on each plant was counted. While this approach is unlikely to catch every single berry, the number of berries lost should be very similar for both species of plant. The experiment consisted of five blocks of two plant arrangements: (1) an isolated $V$. cylindracem and (2) a $V$. cylindraceum standing adjacent to a $L$. formosa. Within a block the solitary and the paired $V$. cylindracem were at least $30 \mathrm{~m}$ apart and all groups were at least $100 \mathrm{~m}$ apart. The number of fruits removed from each tree at the end of the experiment was calculated as:

Fruit $_{\text {removed }}=$ fruit $_{\text {initial }}-\left(\right.$ fruit $_{\text {final }}+$ fruit $\left._{\text {fallen }}\right)$

The number of fruit removed by birds from each plant was explored via repeated measures General Linear Model with the experimental groups of trees included as subjects. Post hoc pairwise comparisons between treatments were performed with paired $t$ tests, applying a Bonferroni correction.

\section{Results}

Fruit abundance

Overall, 837,101 fruits of 68 plant species were counted or estimated on the four sampled plots in 2005. Regarding the diversity of fruiting species, 34 (50\%) were exotic, while 32 species $(47 \%)$ were native and two species (3\%), Fragaria vesca and Prunella vulgaris, were of uncertain origin. Regarding the number of fruits available, the majority were from native species $(511,598$ fruits, representing $61 \%$ of all produced fruits), most of these being from endemic trees, chiefly Ilex perado, Juniperus brevifolia and Viburnum treleasei, and comprising $54 \%$ of all fruits. Among exotic species, which together formed $39 \%$ of the fruits displayed (324,703 fruits), the more important species were C. arborea, $H$. gardnerianum and $L$. formosa (Fig. 2).

Integration of exotic seeds into seed dispersal networks

Overall 1,121 droppings were collected from nine bird species during 965 trapping hours. A total of 1,423 intact seeds were found in 274 droppings (24\%) and were produced by seven of the nine bird species present in the study area (Fig. 2). Blackcap (Sylvia atricapilla) and Blackbird (Turdus merula), were the main seed dispersers followed by Robin (Erythacus rubecula). Each bird that consumed fruit dispersed a large proportion of exotic seeds (usually present in more than $50 \%$ of the droppings). Droppings contained entire seeds from 41 plant species, these being 


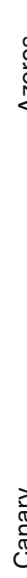
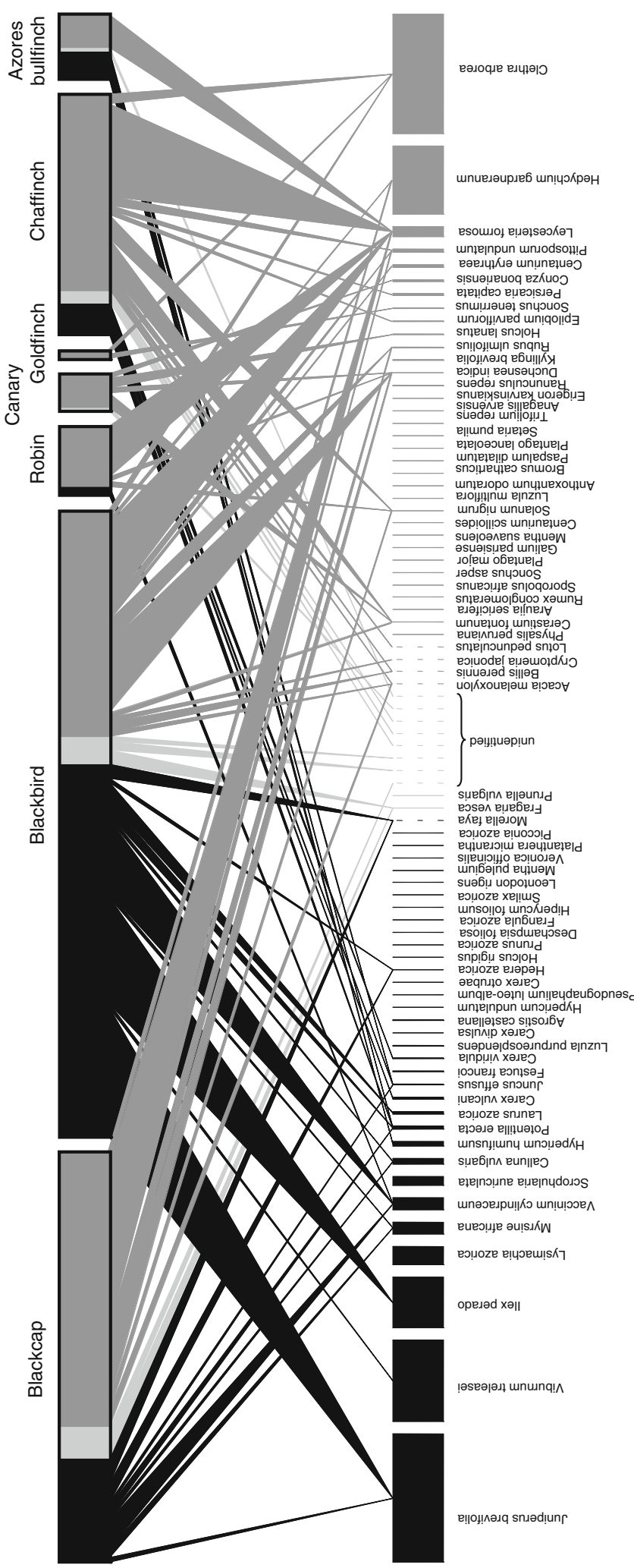

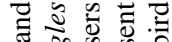

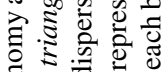

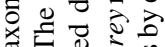

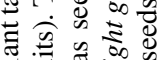

$\bar{a} \cdot \Xi_{0}=2$

के प्रें

すे

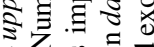

o $\not .0$

的웡

음 $\bar{a}$

施.

के

궁영

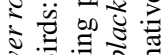

के थे]

윙ㅎㅀ

б

을

흠

जे

$\therefore$ 둥

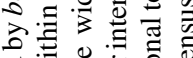

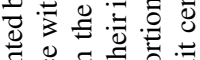

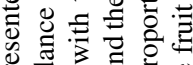

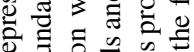

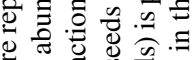

类

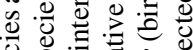

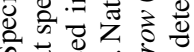

क ज्ञ

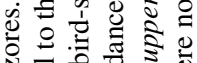

文西要

ป.

훙ㅎㅇ

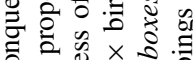

들

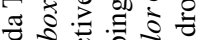

들 응

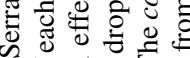

t

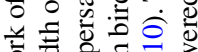

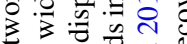

Ð ठ ठ

ब

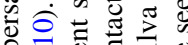

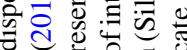

उ न 원

क屯 ए ए

刃

可

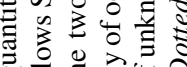

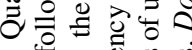

$\sim \stackrel{00}{\Xi} \stackrel{\square}{\Xi}$.

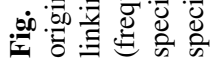


linked to dispersers by 74 unique interactions (Fig. 2). Overall, the seed dispersal web indicates that the local seed dispersers have integrated exotic fruits into their diets, to the extent that almost two-thirds of all seeds dispersed are exotic. The seed dispersal network was generalized with most bird species dispersing several seed species (mean 10.6; range 2-24) and most seeds being dispersed by more than one bird species (mean 1.8 ; range 1-5).

From the 32 seed species that could be identified, 14 were native, 18 were exotic, and the origin of 10 species (which together comprised only $4 \%$ of the seed recovered) could not be ascertained. Among the droppings that contained seeds, $46 \%$ contained seeds of native species while $65 \%$ contained exotic seeds and $11 \%$ of the droppings contained both native and exotic seeds. Considering the absolute number of individual seeds recovered from the droppings, 843 seeds (59\%) were exotic while 521 seeds (37\%) were native and $4 \%$ could not be identified to species level (morphotypes). These proportions reflect a bias towards the dispersal of exotic seeds, in relation to their relative abundance $(G=20.6 ; \quad d f=1$; $P<0.001)$. This result is largely influenced by a few highly attractive species found in the droppings; $L$. formosa and Duchesnea indica among the most common exotic species dispersed. Whereas neither $L$. formosa and D. indica are considered among the most serious invasive species in the Azores (Silva et al. 2008), seeds of several highly invasive plants were found in the bird droppings, namely seeds of $H$. gardnerianum were found in four droppings $(1.6 \%)$, seeds of Acacia melanoxylon in five droppings (1.8\%), Pittosporum undulatum in nine droppings (3.3\%) and Clethra arborea in five droppings (1.8\%).

The strength of fruits as resources for birds was not affected by their origin $(F=2.01 ; d f=1 ; P=$ $0.164)$, abundance $(F=0.12 ; d f=1 ; P=0.728)$, or the interaction between these factors $(F=0.86$; $d f=1 ; P=0.362$ ).

\section{Evaluating the consequences for network structure}

Our predictions that the exotic sub-web will have higher linkage density, mean number of dispersers per plant, and interaction evenness than the native subweb were correct (Table 1). The robustness of the exotic sub-web was marginally, but not significantly higher than in the native sub-web. For all the above parameters except linkage density (which is additive), the values of the whole network were between the values obtained for the native and the exotic sub-webs. Only network connectance was affected in the opposite way, being higher in the native sub-web and lower in the whole network.

\section{Evaluating competition for seed dispersers}

Birds showed no preference for fruits of L. formosa or $V$. cylindraceum, consuming them equally (mean $\pm \mathrm{SE}=96 \pm 15$ and $102 \pm 23$, respectively; $t_{(4)}=-0.20 ; \quad P=0.854 ; \quad$ Bonferroni corrected $\alpha=0.025$ ) when both species were presented side by side in similar fruit displays (Fig. 3). However, significantly fewer fruits $(56.7 \%$ fewer $)$ were removed from $V$. cylindraceum plants standing next to the exotic $L$. formosa than from isolated plants (mean $\pm \mathrm{SE}=102 \pm 23$ and $180 \pm 20$, respectively; $t_{(4)}=-4.41 ; P=0.012$; Bonferroni corrected $\alpha=0.025)$.

Table 1 Quantitative network descriptors for the Azores seed dispersal network (see "Methods" for parameter descriptions)

\begin{tabular}{lccc}
\hline Parameter & $\begin{array}{c}\text { Whole } \\
\text { network }\end{array}$ & $\begin{array}{l}\text { Exotic } \\
\text { sub-web }\end{array}$ & $\begin{array}{c}\text { Native } \\
\text { sub-web }\end{array}$ \\
\hline Connectance & & & \\
$\quad$ Observed & 0.258 & 0.325 & 0.333 \\
$\quad$ Standardized $\left(\% \mathrm{M}_{0}\right)$ & $73.5^{*}$ & $77.5^{*}$ & $79.1^{*}$ \\
Linkage density & & & \\
$\quad$ Observed & 6.26 & 4.23 & 3.46 \\
$\quad$ Standardized $\left(\% \mathrm{M}_{0}\right)$ & $73.8^{*}$ & $84.4^{*}$ & $71.4^{*}$ \\
Mean number of dispersers per plant & & \\
$\quad$ Observed & 2.61 & 3.35 & 1.56 \\
$\quad$ Standardized $\left(\% \mathrm{M}_{0}\right)$ & $77.1 *$ & $84.0^{*}$ & $73.0^{*}$ \\
Interaction evenness & & & \\
$\quad$ Observed & 0.84 & 0.84 & 0.79 \\
$\quad \begin{array}{l}\text { Standardized }\left(\% \mathrm{M}_{0}\right) \\
\text { Robustness }\end{array}$ & $98.0^{*}$ & 100.4 & $94.5^{*}$ \\
$\quad \begin{array}{l}\text { Observed } \\
\text { Standardized }\left(\% \mathrm{M}_{0}\right)\end{array}$ & 95.5 & 108.8 & $82.6^{*}$ \\
\hline
\end{tabular}

For each parameter the real or "observed" value is presented as well as its "standardized" measure in the form of a percentage in relation to the same descriptor for 1,000 randomly generated networks of the same size. This latter "standardized" measure facilitates the comparison across the three networks, which would otherwise be hindered by their different sizes. Observed values outside the $95 \%$ confidence limits around the mean of the null models are marked with $*$ 


\section{Discussion}

Although native fruits are more common in the study area, the seed dispersal network was dominated by exotic seeds (59\%). The proportion of exotic seeds dispersed in this Azorean forest is higher than in other archipelagos; for example, birds consumed on average $19 \%$ of exotic fruits in New Zealand (Williams and Karl 1996), $15 \%$ in Hawaii (Foster and Robinson 2007), and $5 \%$ in the Galápagos (Heleno et al. 2012b). The level to which exotic plants have infiltrated seed dispersal network in one of the last native forests in the Azores is alarming as it is to the point that the network is no longer characterized by native seeds.

Integration of exotic seeds into seed dispersal networks

Contrary to our expectations, and despite being less abundant in the study area, exotic species were as important as native species for dispersers. This result suggests that exotic plants might be disproportionally attractive to birds, which will consume their fruits and disperse their seeds. Seeds of highly invasive species: H. gardnerianum, P. undulatum and A. melanoxylon were found in droppings of Blackcaps, Blackbirds and Chaffinches. These three plant species are included in the list of the World's worst invasive species (Global Invasive Species Database 2010) and are directly threatening the native laurel forest (Ramos 1996; Heleno et al. 2010) and consequently also threatening the last remaining population of the Azores bullfinch

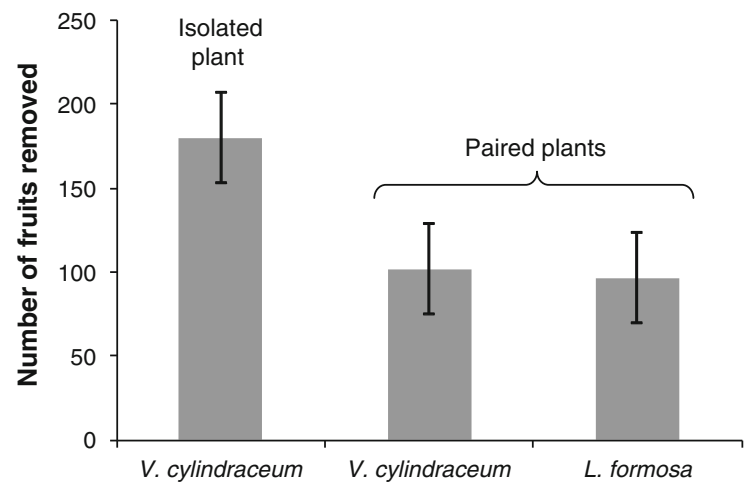

Fig. 3 Number of fruits removed from Leycesteria formosa and Vaccinium cylindraceum trees under two treatments: $L$. formosa side by side with $V$. cylindraceum, and an isolated tree of $V$. cylindraceum. Error bars represent the standard error which is found at this site (Ceia et al. 2011). We recorded entire seeds of $P$. undulatum and A. melanoxylon in droppings of birds captured more than $300 \mathrm{~m}$ away from the nearest adult tree. Even though the proportion of seeds from highly invasive species was low, there is evidence that long distance dispersal events can be critically important at accelerating the invasion process (Nathan and Muller-Landau 2000). Several studies reported the facilitation of plant invasions by mutualistic interactions, for example Williams (2006) suggested that Blackbirds make a major contribution to the spread of woody weeds in New Zealand, and several native and exotic dispersers facilitate the spread of Opuntia spp. in the Mediterranean region and in the Canary islands among others (Padrón et al. 2011). To date, the vast majority of seed dispersal research has focused on particular species or a small component of the seed dispersing fauna. Alternatively, to consider the more typical situation of multiple invasive and native plant species, simultaneously interacting with seed dispersers, is likely to further advance our understanding and managing of plant invasions (Gosper et al. 2005).

Evaluating the consequences for network structure

An ideal experimental design to evaluate the effect of invasion on seed dispersal networks would consist of comparing independent site-specific networks along a gradient of invasion. This design has not yet been used though as it is logistically very challenging and necessitates a gradient, unconfounded by other factors, to be available for use. Such gradients are extremely difficult to find in many islands and virtually do not exist in the Azores. The difficulty in planning robust designs to statistically test changes in replicated networks is extremely difficult as a result of the large sampling effort needed to build representative and well-resolved networks. This limitation is frequently circumvented by running simulations with null models like the ones presented here (e.g. Fortuna and Bascompte 2006), by conducting meta-analysis of networks (e.g. Thébault and Fontaine 2010) or focusing on species-level interaction patterns instead of emergent network properties (e.g. Memmott and Waser 2002). Although the first steps have been given towards statistically evaluate the effect of invasion on pollination networks (Padrón et al. 2009) and for comparing patterns of seed dispersal between islands and 
continents (González-Castro et al. 2012), we are aware of a single study reporting the effects of plant invasions on seed dispersal networks, that of Heleno et al. (2012b) in the Galápagos.

Our study revealed that exotic plants attracted on average more seed dispersers than native plants, and thereby their integration increased linkage density, the mean number of dispersers, and the network robustness. For these descriptors, the whole network exhibited values that are between the values of the native (more specialist) and the exotic (more generalist) subwebs, reflecting a tendency of exotic plants to inflate such descriptors. The initially counter-intuitive result that exotic plants tend to increase the robustness of plants to the loss of dispersers is caused by an increase in the linkage level, and thus on a lower probability of any individual plant losing all its dispersers. The integration of exotic plants increased interaction evenness, this is consistent with the generalism of many exotic species which attract a diverse array of frugivores and thus act as stabilizing the distribution of interaction frequencies. Connectance, which is largely related to the average generalisation of species in the network (Warren 1994; Heleno et al. 2012a), decreased with exotic plants integration. In pollination studies, exotic plants have been shown to reduce connectance (e.g. Memmott and Waser 2002) or have no effect over it (e.g. Padrón et al. 2009; Vilà et al. 2009). Our expectation of increased connectance was based on the assumption that many invasive plants tend to be highly attractive to frugivores (Renne et al. 2002). The reduction in network connectance, could be due to the abundance of naturalized herbs (e.g. Sonchus asper, Plantago major, Anthoxanthum odoratum, etc.; Fig. 1), which largely increase the number of possible interactions (network size) but attract few dispersers, thereby reducing the proportion of realized links.

\section{Evaluating competition for seed dispersers}

Our results suggest that most frugivorous birds do not discriminate between fruits of the native $V$. cylindraceum and the exotic L. formosa, consuming them equally when these are simultaneously presented. However, while the presence of the exotic plant did not seem to attract more frugivores, the presence of this exotic plant resulted in a net negative effect of the removal of the native plants that had to share the dispersers of their fruits. Thus significantly fewer $(56.7 \%)$ V. cylindraceum were removed by birds when in close range to an exotic plant. Similar negative interactions between native and exotic species mediated by mutualists have been documented in pollination systems with exotic plants reducing pollinator visitation and thereby seed set of co-occurring native and alien plants (e.g. Chittka and Schurkens 2001). Few studies evaluated the influence of adjacent fruiting plants on the seed dispersal effectiveness of focal trees, and these had mostly contrasting results (e.g. Carlo 2005; Saracco et al. 2005; Blendinger and Villegas 2011). While on a relatively small scale our experiment is, to our knowledge, the first to document a negative effect of an invasive plant in the seed dispersal performance of co-occurring native plants. This results support the prevalence of competition, rather than facilitation between these two plant species. In our experiment it is not possible to conclude that competition is specifically related to the exotic status of $L$. formosa and to exclude the hypothesis of similar effects between co-occurring pairs of native species. Nevertheless, the expected range expansion of this and other exotic species is likely to increase the prevalence of exotic-native competing pairs of plants at the landscape level. The equal importance (i.e. strength) of exotic and native species, despite the higher abundance of the latter, further supports the idea that exotic plants are superior competitors than natives.

While our study is illustrative of the importance of birds for the spread of intact exotic seeds in Serra da Tronqueira, we could not quantitatively link seed dispersal with the dynamics of native and exotic plant populations (i.e. dispersal effectiveness). Previous studies in this area suggest that exotic seedlings are more competitive in early life-stages than seedlings from native species (Heleno et al. 2010), and that monotonic stands of exotic plants can have negative effects on plant, insect and vertebrate diversity and biomass (Ramos 1996; Ceia et al. 2009; Heleno et al. 2009). However, the relationship between seed dispersal and changes in the adult plant populations deserves further attention (Côrtes et al. 2009; CalviñoCancela 2011). Furthermore, future studies that simultaneously consider the facilitation versus competition between whole natural assemblages of native and exotic plants will be important to confirm the generality of these results. 
The Azores seed dispersal network is highly generalized as is typical of seed dispersal systems (Malmborg and Willson 1988). The fact that seed dispersal is such a generalized process is both positive and negative news for habitat conservation: on one hand the redundancy of dispersers is likely to confer some degree of robustness for animal-dispersed native plants to the local extinction of dispersers; while on the other hand it provides invasive plants with a suite of well established mutualists (Gosper et al. 2005; Buckley et al. 2006). In this sense, birds are part of the solution and part of the problem and the challenge facing conservation ecologists is to study possible mechanisms that allow us to increase the former and reduce the latter.

Acknowledgments We thank the LIFE-Priolo team, particularly Ricardo Ceia, Hugo Sampaio, Carlos Silva and Sandra Parejo for all the logistic support in the field, Márcia Santos, Bronwen Lester and Catarina Heleno for help during fieldwork, and Rachel Gibson and Mariano Devoto for sharing $\mathrm{R}$ code.

\section{References}

Aslan CE, Rejmánek M (2010) Avian use of introduced plants: ornithologist records illuminate interspecific associations and research needs. Ecol Appl 20(4):1005-1020. doi:10.1890/ 08-2128.1

Bartuszevige AM, Gorchov DL (2006) Avian seed dispersal of an invasive shrub. Biol Invasions 8(5):1013-1022. doi: 10.1007/s10530-005-3634-2

Bascompte J, Jordano P, Olesen J (2006) Asymmetric coevolutionary networks facilitate biodiversity maintenance. Science 312:431-433. doi:10.1126/science. 1123412

Berlow EL (1999) Strong effects of weak interactions in ecological communities. Nature 398(6725):330-334

Bersier LF, Banasek-Richter C, Cattin MF (2002) Quantitative descriptors of food-web matrices. Ecology 83(9): 2394-2407. doi:10.2307/3071801

Blendinger PG, Villegas M (2011) Crop size is more important than neighborhood fruit availability for fruit removal of Eugenia uniflora (Myrtaceae) by bird seed dispersers. Plant Ecol 212(5):889-899. doi:10.1007/s11258-010-9873-Z

Buckley YM, Anderson S, Catterall CP, Corlett RT, Engel T, Gosper CR, Nathan R, Richardson DM, Setter M, Spiegel O, Vivian-Smith G, Voigt FA, Weir JES, Westcott DA (2006) Management of plant invasions mediated by frugivore interactions. J Appl Ecol 43(5):848-857. doi: 10.1111/j.1365-2664.2006.01210.x

Calviño-Cancela M (2011) Simplifying methods to assess site suitability for plant recruitment. Plant Ecol 212(8): 1375-1383. doi:10.1007/s11258-011-9913-3

Carlo TA (2005) Interspecific neighbors change seed dispersal pattern of an avian-dispersed plant. Ecology 86(9): 2440-2449. doi:10.1890/04-1479
Carvalheiro LG, Barbosa ERM, Memmott J (2008) Pollinator networks, alien species and the conservation of rare plants: Trinia glauca as a case study. J Appl Ecol 45(5): 1419-1427. doi:10.1111/j.1365-2664.2008.01518.x

Ceia R, Heleno R, Ramos J (2009) Summer abundance and ecological distribution of passerines in native and exotic forests in São Miguel, Azores. Ardeola 56(1):25-39

Ceia RS, Sampaio HL, Parejo SH, Heleno RH, Arosa ML, Ramos JA, Hilton GM (2011) Throwing the baby out with the bathwater: does laurel forest restoration remove a critical winter food supply for the critically endangered Azores bullfinch? Biol Invasions 13:93-104. doi:10.1007/s10530010-9792-x

Chittka L, Schurkens S (2001) Successful invasion of a floral market-an exotic Asian plant has moved in on Europe's river-banks by bribing pollinators. Nature 411(6838):653. doi: $10.1038 / 35079676$

Cordeiro NJ, Patrick DAG, Munisi B, Gupta V (2004) Role of dispersal in the invasion of an exotic tree in an East African submontane forest. J Trop Ecol 20:449-457. doi:10.1017/ s026646740400152x

Côrtes MC, Cazetta E, Staggemeier VG, Galetti M (2009) Linking frugivore activity to early recruitment of a bird dispersed tree, Eugenia umbelliflora (Myrtaceae) in the Atlantic rainforest. Austral Ecol 34(3):249-258. doi:10.1111/j.1442-9993. 2009.01926.x

Dias E, Elias R, Melo C, Mendes C (2007) Biologia e ecologia das florestas das Ilhas-Açores. In: Silva JS (ed) Açores e Madeira: a floresta das Ilhas, vol 6. Publico, Fundação Luso-Americana, Lisbon, pp 51-80

Dormann C, Gruber B, Frund J (2008) Introducing the bipartite package: analysing ecological networks. R News $8(2)$ : 8-11

Dormann CF, Fründ J, Blüthgen N, Gruber B (2009) Indices, graphs and null models: analyzing bipartite ecological networks. Open J Ecol 2:7-24

Duffy JE, Carinale BJ, France KE, McIntyre PB, Thébault E, Loreau M (2007) The functional role of biodiversity in ecosystems: incorporating trophic complexity. Ecol Lett 10(6):522-538. doi:10.1111/j.1461-0248.2007.01037.x

Dunne JA, Williams RJ, Martinez ND (2002) Network structure and biodiversity loss in food webs: robustness increases with connectance. Ecol Lett 5(4):558-567. doi:10.1046/ j.1461-0248.2002.00354.x

Estrada E (2007) Food webs robustness to biodiversity loss: the roles of connectance, expansibility and degree distribution. J Theor Biol 244(2):296-307. doi:10.1016/j.jtbi.2006. 08.002

Evans DM, Pocock MJO, Brooks J, Memmott J (2011) Seeds in farmland food-webs: resource importance, distribution and the impacts of farm management. Biol Conserv 144(12): 2941-2950. doi:10.1016/j.biocon.2011.08.013

Fernandez-Palacios JM, de Nascimento L, Otto R, Delgado JD, Garcia-del-Rey E, Arevalo JR, Whittaker RJ (2011) A reconstruction of Palaeo-Macaronesia, with particular reference to the long-term biogeography of the Atlantic island laurel forests. J Biogeogr 38(2):226-246. doi:10.1111/ j.1365-2699.2010.02427.x

Fortuna MA, Bascompte J (2006) Habitat loss and the structure of plant-animal mutualistic networks. Ecol Lett 9(3): 278-283. doi:10.1111/j.1461-0248.2005.00868.x 
Foster JT, Robinson SK (2007) Introduced birds and the fate of Hawaiian rainforests. Conserv Biol 21(5):1248-1257. doi: 10.1111/j.1523-1739.2007.00781.x

Gibson R, Knott B, Eberlein T, Memmott J (2011) Sampling method influences the structure of plant-pollinator networks. Oikos 120(6):822-831

Global Invasive Species Database (2010) Global invasive species database. http://www.issg.org/database

González-Castro A, Traveset A, Nogales M (2012) Seed dispersal interactions in the Mediterranean region: contrasting patterns between islands and mainland. J Biogeogr. doi: 10.1111/j.1365-2699.2012.02693.x

Gosper CR, Stansbury CD, Vivian-Smith G (2005) Seed dispersal of fleshy-fruited invasive plants by birds: contributing factors and management options. Divers Distrib 11(6):549-558. doi:10.1111/j.1366-9516.2005.00195.x

Heleno RH, Ceia RS, Ramos JA, Memmott J (2009) The effect of alien plants on insect abundance and biomass: a food web approach. Conserv Biol 23(2):410-419. doi:10.1111/ j.1523-1739.2008.01129.x

Heleno RH, Lacerda I, Ramos JA, Memmott J (2010) Evaluation of restoration effectiveness: community response to the removal of alien plants. Ecol Appl 20(5):1191-1203. doi:10.1890/09-1384.1

Heleno RH, Ross G, Everard A, Ramos JA, Memmott J (2011) On the role of avian seed predators as seed dispersers. Ibis 153:199-203. doi:10.1111/j.1474-919X.2010.01088.x

Heleno R, Devoto M, Pocock M (2012a) Connectance of species interaction networks and conservation value: is it any good to be well connected? Ecol Ind 14(1):7-10. doi:10.1016/ j.ecolind.2011.06.032

Heleno R, Olesen J, Nogales M, Vargas P, Traveset A (2012b) Seed dispersal networks in the Galápagos and the consequences of alien plant invasions. Proc R Soc B 280. doi: 10.1098/rspb.2012.2112

Herrera CM (1995) Plant-vertebrate seed dispersal systems in the Mediterranean: ecological, evolutionary, and historical determinants. Annu Rev Ecol Syst 26:705-727. doi:10.1146/ annurev.ecolsys.26.1.705

Jordano P (1987) Patterns of mutualistic interactions in pollination and seed dispersal-connectance, dependence asymmetries, and coevolution. Am Nat 129(5):657-677. doi: $10.1086 / 284665$

Kawakami K, Mizusawa L, Higuchi H (2009) Re-established mutualism in a seed-dispersal system consisting of native and introduced birds and plants on the Bonin Islands, Japan. Ecol Res 24(4):741-748. doi:10.1007/s11284008-0543-8

Linnebjerg JF, Hansen DM, Bunbury N, Olesen JM (2010) Diet composition of the invasive red-whiskered bulbul Pycnonotus jocosus in Mauritius. J Trop Ecol 26(03):347-350. doi:10.1017/S0266467409990617

MacArthur R, Wilson E (1967) The theory of island biogeography. Princeton University Press, Princeton

Malmborg PK, Willson MF (1988) Foraging ecology of avian frugivores and some consequences for seed dispersal in an Illinois Woodlot. Condor 90(1):173-186. doi:10.2307/ 1368446

MEA (2005) Millennium Ecosystem Assessment-ecosystems and human well-being: a synthesis. Island Press, Washington, DC
Memmott J, Waser NM (2002) Integration of alien plants into a native flower-pollinator visitation web. Proc R Soc B 269(1508):2395-2399. doi:10.1098/rspb.2002.2174

Memmott J, Gibson R, Carvalheiro L, Henson K, Heleno R, Lopezaraiza M, Pearce S (2007) The conservation of ecological interactions. In: Stewart AA, New TR, Lewis OT (eds) Insect conservation biology. The Royal Entomological Society, London, pp 226-244

Milton SJ, Wilson JRU, Richardson DM, Seymour CL, Dean WRJ, Iponga DM, Proches S (2007) Invasive alien plants infiltrate bird-mediated shrub nucleation processes in arid savanna. J Ecol 95(4):648-661. doi:10.1111/j.1365-2745. 2007.01247.x

Montesinos-Navarro A, Segarra-Moragues JG, Valiente-Banuet A, Verdú M (2012) The network structure of plant-arbuscular mycorrhizal fungi. New Phytol 194(2):536-547. doi:10.1111/j.1469-8137.2011.04045.x

Nathan R, Muller-Landau HC (2000) Spatial patterns of seed dispersal, their determinants and consequences for recruitment. Trends Ecol Evol 15(7):278-285. doi:10.1016/ S0169-5347(00)01874-7

Olesen JM, Eskildsen LI, Venkatasamy S (2002) Invasion of pollination networks on oceanic islands: importance of invader complexes and endemic super generalists. Divers Distrib 8(3):181-192. doi:10.1046/j.1472-4642.2002. 00148.x

Padrón B, Traveset A, Biedenweg T, Díaz D, Nogales M, Olesen JM (2009) Impact of alien plant invaders on pollination networks in two archipelagos. PLoS ONE 4(7):e6275. doi: 10.1371/journal.pone.0006275

Padrón B, Nogales M, Traveset A, Vilà M, Martinez-Abrain A, Padilla DP, Marrero P (2011) Integration of invasive Opuntia spp. by native and alien seed dispersers in the Mediterranean area and the Canary Islands. Biol Invasions 13(4):831-844. doi:10.1007/s10530-010-9872-y

R Development Core Team (2010) R: a language and environment for statistical computing. R Foundation for Statistical Computing, Vienna

Ramos JA (1996) Introduction of exotic tree species as a threat to the Azores bullfinch population. J Appl Ecol 33(4): 710-722. doi:10.2307/2404942

Renne IJ, Barrow WC, Randall LAJ, Bridges WC (2002) Generalized avian dispersal syndrome contributes to Chinese tallow tree (Sapium sebiferum, Euphorbiaceae) invasiveness. Divers Distrib 8(5):285-295. doi:10.1046/j.1472-4642. 2002.00150.x

Saracco JF, Collazo JA, Groom MJ, Carlo TA (2005) Crop size and fruit neighborhood effects on bird visitation to fruiting Schefflera morototoni trees in Puerto Rico. Biotropica 37(1):81-87

Schaeffer H (2002) Flora of the Azores a field guide. Margraf Verlag, Weikersheim

Schupp EW, Jordano P, Gómez JM (2010) Seed dispersal effectiveness revisited: a conceptual review. New Phytol 188:333-353. doi:10.1111/j.1469-8137.2010.03402.x

Silva LD (2001) Plantas vasculares invasoras no Arquipélago dos Açores - PhD thesis. University of the Azores, Ponta Delgada

Silva IA, Figueiredo RAd, Matos DMdS (2008) Feeding visit time of fruit-eating birds in Cerrado plants revisiting the predation risk model. Rev Bras Zool 25(4):682-688 
Silva L, Moura M, Schaefer H, Rumsey F, Dias EF (2010) List of vascular plants (Tracheobionta). In: Borges PAV, Costa A, Cunha R et al (eds) A list of the terrestrial and marine biota from the Azores. Princípia, Cascais, pp 131-155

SPEA (2005) Plano de gestão da ZPE Pico da Vara/Ribeira do Guilherme

Stansbury CD (2001) Dispersal of the environmental weed Bridal Creeper, Asparagus asparagoides, by Silvereyes, Zosterops lateralis, in south-western Australia. Emu 101(1):39-45. doi:10.1071/mu00069

Thébault E, Fontaine C (2010) Stability of ecological communities and the architecture of mutualistic and trophic networks. Science 329:853-856. doi:10.1126/science.1188 321

Traveset A, Richardson DM (2011) Mutualisms: key drivers of invasions... key casualties of invasions. Fifty years of invasion ecology: the legacy of Charles Elton. WileyBlackwell, Oxford

Tutin TG (1953) The vegetation of the Azores. J Ecol 41(1): 53-61
Vilà M, Bartomeus I, Dietzsch AC, Petanidou T, SteffanDewenter I, Stout JC, Tscheulin T (2009) Invasive plant integration into native plant-pollinator networks across Europe. Proc R Soc B 276(1674):3887-3893. doi:10.1098/ rspb.2009.1076

Vitousek PM, D'Antonio CM, Loope LL, Westbrooks R (1996) Biological invasions as global environmental change. Am Sci 84(5):468-478

Warren PH (1994) Making connections in food webs. Trends Ecol Evol 9(4):136-141. doi:10.1016/0169-5347(94) 90178-3

Whittaker RJ, Fernández-Palacios JM (2007) Island biogeography: ecology, evolution, and conservation. Oxford University Press, Oxford

Williams PA (2006) The role of blackbirds (Turdus merula) in weed invasion in New Zealand. N Z J Ecol 30(2):285-291

Williams PA, Karl BJ (1996) Fleshy fruits of indigenous and adventive plants in the diet of birds in forest remnants, Nelson, New Zealand. N Z J Ecol 20(2):127-145

Wolfram Research (1999) Mathematica, version 6.0. Champaign 